\section{Prenatal diagnosis of hemoglobinopathies: from fetoscopy to coelocentesis}

\author{
Gianfranca Damiani, ${ }^{1}$ \\ Margherita Vinciguerra, ${ }^{2}$ Cristina Jakil, ${ }^{1}$ \\ Monica Cannata, ${ }^{2}$ Filippo Cassarà, ${ }^{2}$ \\ Francesco Picciotto, ${ }^{1}$ Giovanna Schillaci, ${ }^{1}$ \\ Valentina Cigna, ${ }^{1}$ Disma Renda, ${ }^{2}$ \\ Aldo Volpes, ${ }^{3}$ Francesca Sammartano, ${ }^{3}$ \\ Samuela Milone, ${ }^{3}$ Adolfo Allegra, ${ }^{3}$ \\ Cristina Passarello, ${ }^{2}$ Filippo Leto, ${ }^{2}$ \\ Antonino Giambona ${ }^{2}$ \\ 'Department of Gynecology and \\ Obstetrics, Prenatal Diagnosis Service, \\ Villa Sofia-Cervello, Hospital, Palermo; \\ 2Department of Hematology for Rare \\ Diseases of Blood and Blood-Forming \\ Organs, Laboratory for Molecular \\ Prenatal of Hemoglobinopathies, Villa \\ Sofia-Cervello Hospital, Palermo; \\ ${ }^{3}$ Andros Day Surgery, Reproductive \\ Medicine Unit, Palermo, Italy
}

\section{Abstract}

Prenatal diagnosis of hemoglobinopathies involves the study of fetal material from blood, amniocytes, trophoblast coelomatic cells and fetal DNA in maternal circulation. Its first application dates back to the $70 \mathrm{~s}$ and it involves globin chain synthesis analysis on fetal blood. In the 1980s molecular analysis was introduced as well as amniocentesis and chorionic villi sampling under high-resolution ultrasound imaging. The application of direct sequencing and polymerase chain reactionbased methodologies improved the DNA analysis procedures and reduced the sampling age for invasive prenatal diagnosis from 18 to 16 11 weeks allowing fetal genotyping within the first trimester of pregnancy. In the last years, fetal material obtained at 7-8 weeks of gestation by coelocentesis and isolation of fetal cells has provided new platforms on which to develop diagnostic capabilities while non-invasive technologies using fetal DNA in maternal circulation are starting to develop.

\section{Introduction}

Hemoglobinopathies can be subdivided in expression (thalassemias) and structural defects (abnormal hemoglobins). Thalassemias syndromes and the common abnormal hemoglobins $(\mathrm{Hb})$ associated with severe pathology such as hemoglobins S, C and E are a global problem. ${ }^{1}$ They occur at high frequencies mainly in Mediterranean populations and in Africa, Middle East, Central Asia, India, Southern China and the Far East but due to ancient and more recent migrations are now found in many immigration countries all over the world. ${ }^{2-4}$

Migration from native areas has spread hemoglobinopathies to Northern Europe, the Americas and many other immigration areas where these conditions were previously rare or absent. Approximately $1.5 \%$ of the global population is carriers of the $\beta$-thalassemias with about more than 50,000 new affected every year. ${ }^{5,6}$

Well organized control programs based upon information, screening for carrier identification, genetic counseling and prenatal diagnosis have reduced dramatically the numbers of affected newborns (incidence). ${ }^{7,8}$

To date, carrier screening, genetic counseling, and prenatal diagnosis for hemoglobinopathies represent one of the most frequent genetic analyses performed worldwide. ${ }^{9}$

Carrier screening for hemoglobinopathies should be offered to all women in reproductive age and extended to the partner if the woman is suspected or found to be carrier. Ideally, the screening should be done pre-conceptionally or as early as possible in the pregnancy. The traditional basic hematological tests for thalassemia are the measurement of the mean corpuscular volume (MCV), the mean corpuscular hemoglobin value and the quantity of $\mathrm{HbA}_{2}, \mathrm{HbF}$ and the eventual $\mathrm{Hb}$ variants. However, most carriers of $\mathrm{HbS}, \mathrm{HbC}, \mathrm{HbD}$ and other relevant traits are not microcytic. Therefore the results of the blood count should not preclude the separation and measurement of the $\mathrm{Hb}$ fractions and to date the most sensible protocol is to perform separation and measurement using high performance liquid chromatography (HPLC) or capillary electrophoresis (CE) regardless and in parallel with the blood count. If both partners are found to be carriers of relevant and risk related traits the couple should be immediately referred for genetic counseling. ${ }^{10-12}$

Invasive prenatal diagnosis can be performed from 7 weeks of gestation by coelocentesis $^{13}$ to 22 weeks by cordocentesis. ${ }^{14}$ DNA analysis can be done using cells obtained from coelomatic fluid, chorionic villi, ${ }^{15}$ amniotic fluid or fetal blood and molecular defects should be be identified in both parents preferably before or together with prenatal diagnosis. The first attempts of prenatal diagnosis of Hemoglobinopathies was for thalassemia major making use of fetal blood sampling and in vitro globin chain synthesis to measure directly the expression of the mutated genes. ${ }^{16}$ Successively, techniques have been developed to isolate fetal DNA. ${ }^{17}$ Several methods have been used to analyze the DNA including direct
Correspondence: Antonino Giambona, via G.L. Bernini 135, 90145 Palermo, Italy.

Tel.: +39.091 .6802770 - Fax: +39.091 .6885619 .

E-mail: a.giambona@villasofia.it;

giambic@libero.it

Key words: thalassemia, prenatal diagnosis, coelocentesis.

Acknowledgments: the authors are grateful to the Franco and Piera Cutino Foundation 0.N.L.U.S.

Contributions: MV, AG study concept and design, writing the manuscript and critical manuscript revision; $\mathrm{MC}, \mathrm{FC}$ data acquisition and writing the manuscript; FL, CP data analysis and interpretation and critical manuscript revision; GD, CJ, FP, GS, VC, DR final approval of the version to be published; AV, FS, SM, AA agreement to be accountable for all aspects of the work in ensuring that questions related to the accuracy or integrity of any part of the work are appropriately investigated and resolved.

Conflict of interests: the authors declare no potential conflict of interests.

Received for publication: 20 December 2013.

Revision received: 20 May 2014.

Accepted for publication: 21 May 2014.

This work is licensed under a Creative Commons Attribution 3.0 License (by-nc 3.0).

(C) Copyright G. Damiani et al., 2014

Licensee PAGEPress, Italy

Thalassemia Reports 2014; 4:2200

doi:10.4081/thal.2014.2200

identification of the molecular lesion by restriction endonuclease mapping, ${ }^{18}$ determination of the chromosome carrying the abnormal globin gene by linkage using restriction fragment length polymorphisms (RFLPs) ${ }^{19}$ or detection of specific mutations directly with oligonucleotide probes..$^{20} \mathrm{~A}$ grater impulse was given by the advent of polymerase chain reaction (PCR) technology that allowed the development of several PCR-based techniques together with automatic non-radioactive sequencing analysis to perform rapid and safe molecular diagnosis. ${ }^{21}$

\section{Fetal blood sampling: fetoscopy and cordocentesis}

The biological feasibility of prenatal diagnosis of $\beta$-thalassemia was reported for the first time in $1970 .^{22}$ The authors reported also that the erythrocytes of fetus homozygotes for $\beta$-thalassemia are morphologically indistinguishable from normal because the cells are largely filled 
with fetal hemoglobin and their volumes is about $100 \mathrm{fL}$. Other investigators determined the normal range of fetal $\beta \alpha$ and $\gamma$-globin gene synthesis and their ratio in the normal, $\beta$-trait and affected $\beta$-thalassemia fetus. ${ }^{23}$ Diagnosis of $\beta$-thalassemia in the second trimester of pregnancy posed however several problems: i) the use of safe methods to obtain fetal blood without risk for the fetus; ii) the small amount of blood obtained by fetoscopy; iii) fetal blood samples contaminated by maternal cells; iv) low synthesis of $\beta$-chains in the second trimester, i.e. in normal human fetus it is less than $10 \%{ }^{24,25}$ and further reduction of $\beta$-chain synthesis in both $\beta$-trait and affected fetus. Many of these problems were successively solved but the last and not least, which is the emotional burden of interrupting an advanced pregnancy. At beginning of 1974 it was possible to obtain fetal blood during the second trimester of pregnancy at 1820 weeks. $^{26}$ Initially, the technique used for aspiration of fetal blood was placentocentesis ${ }^{27}$ and successively fetoscopy. ${ }^{28}$ The first one involved aspiration of blood from the placenta under ultrasound guidance. ${ }^{29}$ A long 20-gauge spinal needle was introduced transabdominally into the placenta and several small samples of blood were aspirated. The second one involved insertion of a fiberoptic endoscope into the amniotic cavity taking a small sample of fetal blood under direct visualization by passing a long 27-gauge needle through the side-arm of the fetoscopy cannula (Figure 1). Some groups used other approaches consisting of ultrasound guided placement of a needle into the hepatic portion of the umbelical vein or ultrasound guided fetal cardiac puncuture. ${ }^{30}$ The rate of fetal loss reported was variable from center to center, about $4.8 \%$ for prenatal diagnosis of genetic disease in Montreal, $5.1 \%$ rate in the two centers of United States that actively performed fetoscopy, $7.4 \%$ rate for other centers. In about $13 \%$ of cases more than one attempt was necessary to obtain an adequate sample. ${ }^{31}$ The loss rate was significantly higher in the centers in which a smaller numbers of cases were studied, and therefore the presence of an experienced obstetrical team was needed. During aspiration the blood sample must be quickly analyzed to ensure the presence of fetal blood and the absence of maternal contamination. Each sample was immediately analyzed on a Coulter Channelyzer, which detects the difference in size between maternal and fetal red cells due to the large size of fetal erytrocytes (MCV $=100-120 \mathrm{fL}$ ), while MCV in adult cells of $\beta$-thalassemia carriers is usually less than 70 $80 \mathrm{fL}$. This analysis must be conducted in a few seconds, thus the procedure can be stopped as soon as a suitable pure sample has been obtained. The percentage of fetal cells can also be confirmed by Kleihauer-Betke test. ${ }^{32,33}$

\section{Laboratory methods}

All methods used for fetal blood collection are bound to produce samples more or less contaminated with maternal blood. A sample enriched in fetal cells was essential for globin chain synthesis and since fetal and adult erythrocytes differ in several characteristics, such as size, type of hemoglobin, membrane antigens and enzyme levels, ${ }^{34}$ elimination of maternal contamination has been carried out in different ways: i) transfusion of the mother to suppress maternal reticulocyte globin gene synthesis $;{ }^{35}$ ii) fetal red cell concentration with differential agglutination using anti-i serum; ${ }^{36}$ iii) fetal red cell enrichment with antibodies against blood group antigens (ABO, MNs, Rh systems) $;^{37}$ iv) differential lysis of maternal cells with the Orskov-Stewart-Jacobs reaction. ${ }^{38}$ This last method was the most useful, simple and efficient for globin chain synthesis in samples of placental blood with less than 5\% fetal cells. The method is based on differences in the carbonic anhydrase levels of fetal and adult red blood cells and results in selective hemolysis of the contaminating maternal cells. When red cells are suspended in $\mathrm{NH} 4 \mathrm{Cl}$ and NH4HCO3, NH3 enter the cells, if carbonic anhydrase is present, the $\mathrm{CO}_{2}$ convertes to HCO3- which then exchanges for CL-. The latter is trapped by $\mathrm{NH} 4+$ and eventually leads to osmotic lysis after $\mathrm{H}_{2} \mathrm{O}$ also enters the cells. In the fetal cells, the low level of carbonic anydrase is further inhibited by the small amount of acetazolamide and hemolysis occurs much more slowly. Thus the proper choice of concentrations of NH4HCO3 and acetazolamide, combined with an appropriate reaction time, leads to a marked enrichment of fetal cells in mixed samples. ${ }^{39}$

\section{Globin gene biosynthesis and separation}

The fetal blood is incubated with ${ }^{3} \mathrm{H}$-leucine to radiolabeled newly synthesized globin chains, and separated by carboxymethyl cellulose chromatography ${ }^{40}$ (Figure 2). The diagnosis of $\beta$ thalassemia is made when the normal $\beta$-chains are either absent or substantially reduced. The biosynthesis of $\beta$-chains increases slowly during the first and second trimesters. At 16-23 weeks of gestation, the synthesis of $\beta$-chains respect to $\gamma$-chains was calculated between $5-15 \%$ in normal fetuses, between $3.5-6 \%$ in carriers of $\beta$-thalassemia, and below $3 \%$ in case of affected fetuses. ${ }^{41}$ However, each center determined their own synthetic ratios depending from the heterogeneity of $\beta$-thalassemia in that particular region and the technical aspects associated with the separation of newly synthetizes globin chains. Few misdiagnosis were reported from different laboratories associated with technical problems during chain separation but most of the errors occurred in fetuses with $\beta^{+}$-thalassemia major, in which the $\beta \gamma$ ratio was comparable with the one measured in heterozygous conditions. ${ }^{42-44}$

\section{Fetal tissue sampling: amnio- centesis and villocentesis}

The advent of molecular analysis allowed prenatal diagnosis early in the second trimester. In 1980's different techniques have been developed for isolating fetal DNA from material obtained by amniocentesis or chorion

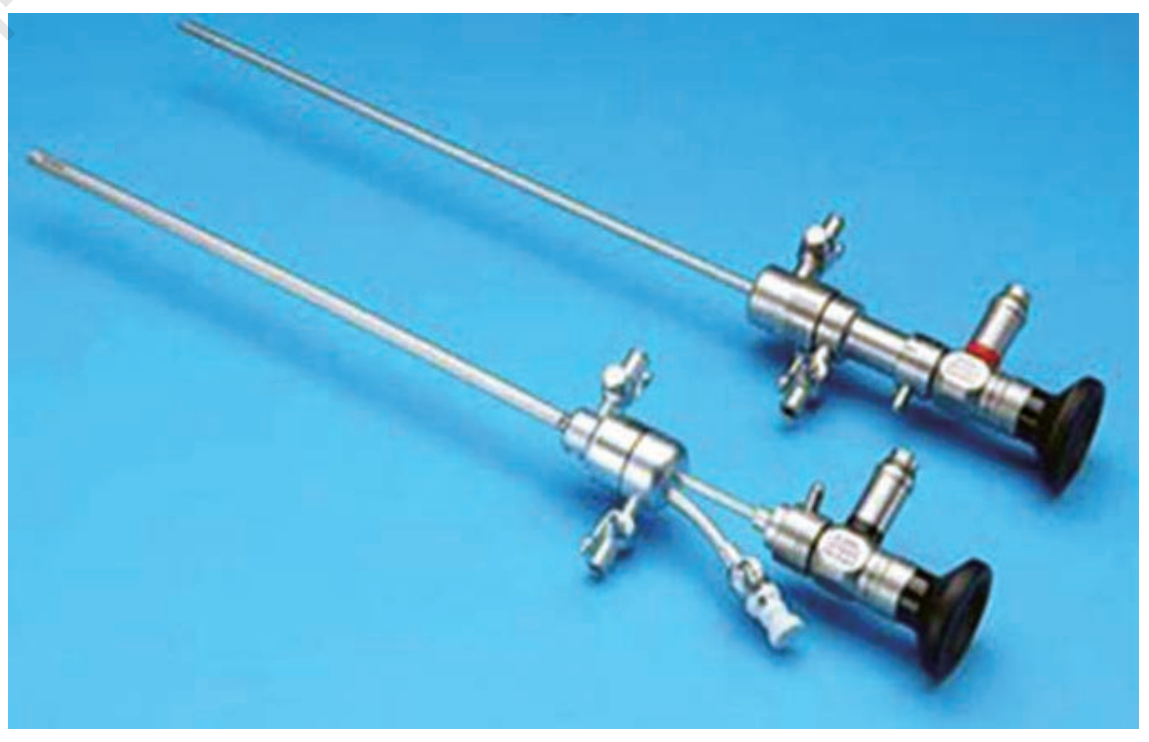

Figure 1. Fetoscopy cannula. 
villi sampling (CVS). Analysis of fetal DNA was done by linkage analysis of the $\beta$-globin gene cluster, by RFLPs or by direct identification of the molecular defect by restriction endonuclease mapping. ${ }^{45}$ Amniocentesis allowed to anticipate prenatal diagnosis of at least two weeks. Fifteen to twenty milliliters of amniotic fluid obtained at 16 weeks gestation contain sufficient fetal cells to provide enough DNA for molecular analysis of globin genes. Subsequently, aspiration of a biopsy of chorionic villi at 11 weeks of gestation provided new practical and psychological advantages. Both methods of sampling were reported safer than fetal blood sampling and the fetal loss rate dropped to $<1 \%$ with amniocentesis and to $<2 \%$ with villocentesis. ${ }^{46-47}$

\section{DNA preparation}

Different methods were described for DNA extraction from whole blood, amniotic cells and chorionic villi. The oldest and still used method in many laboratories is phenol-chloroform extraction. Successively salting-out method was introduced ${ }^{48}$ and different kits, which give sufficient DNA recovery, are commercially available. Before DNA extraction from CVS, microscopic dissection to remove traces of blood and maternal tissue is needed. Usually, 10-20 mg of DNA is obtained from CVS while the yield of DNA obtained by amniotic fluid cells is smaller.

\section{Molecular prenatal diagnosis}

The purpose of DNA-based prenatal diagnosis is always to determine whether the fetus has inherited the disease-causing mutations identified in both parents. A variety of technical innovations have been developed since the early 1970s. The oldest DNA method for hemoglobin disorders was the restriction endonuclease technology and Southern blotting. ${ }^{49-50}$ Today most methods for genetic analysis and prenatal diagnosis are based on PCR, a technique capable of detecting most defects in the wide spectrum of mutations described on the globin genes..$^{51-52}$ Many of the earlier manuals, semi-automated or automated genotyping methods are still used with improved performances of the detection systems.

\section{Restriction fragment length polymorphisms linkage analysis}

Throughout the globin gene clusters there are single base changes that produce either new restriction enzyme sites or remove previously existing ones. These polymorphic sites were very useful in the past because they were employed as markers for the globin gene complexes. The arrangement of RFLPs along the $\beta$ globin gene cluster is not random but specific in different populations. Within any ethnic group it is usual to find individual $\beta$ tha- lassemia mutations strongly associated with a specific RFLP haplotype in the $\beta$ gene cluster. The strong association of a particular gene with a polymorphism is an example of what is termed linkage disequilibrium. Kan and Dozy ${ }^{51}$ first reported the association of a mutant gene, $\mathrm{HbS}$ allele, with a restriction enzyme polymorphism. Although specific $\beta$-thalassemia genes are in linkage disequilibrium with various restriction sites, there is no single DNA polymorphism that is generally useful for analysis of families at risk because the same haplotypes occur frequently in normal subjects in the same populations. Therefore RFLPs were no frequently used for prenatal diagnosis except in a few cases in which individual
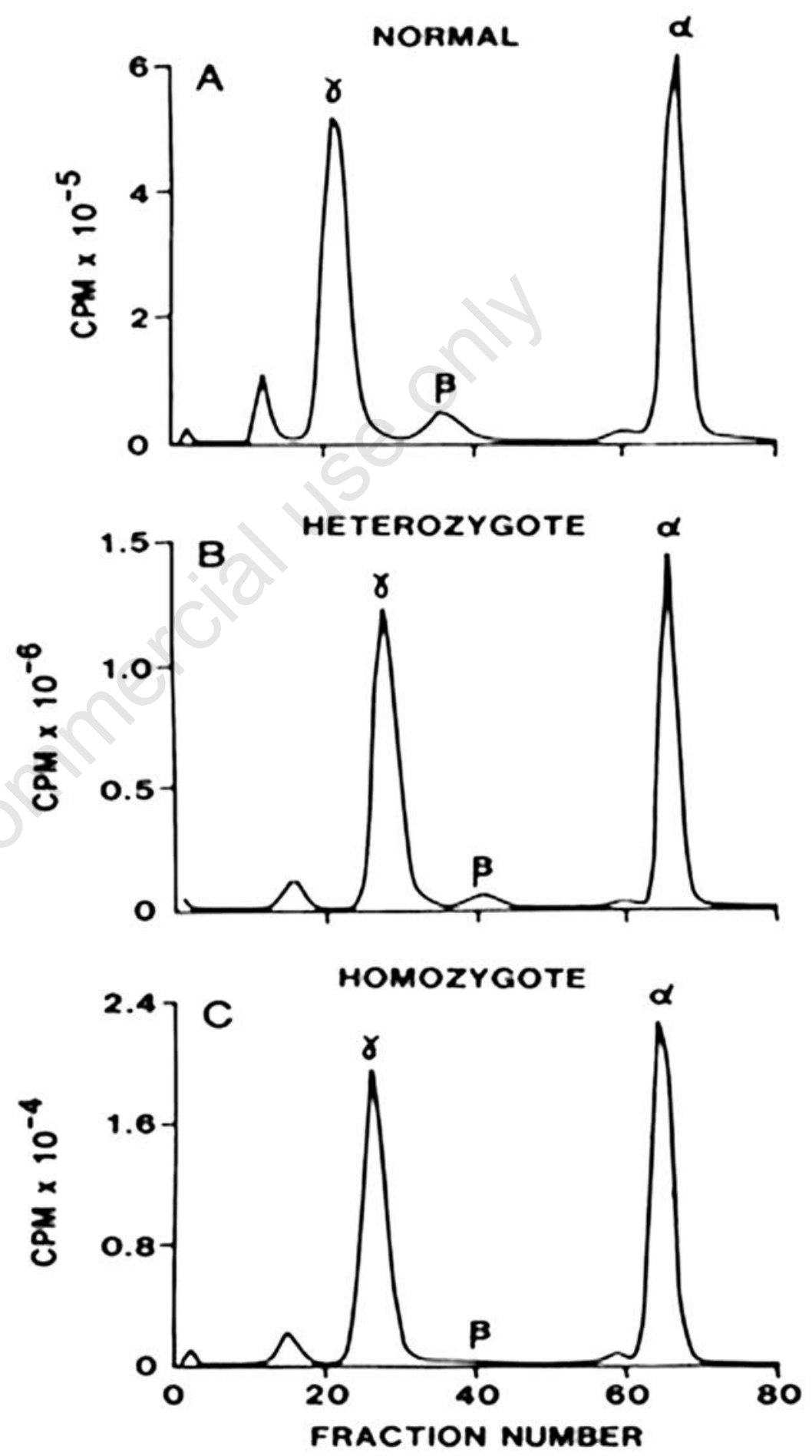

Figure 2. Globin gene chains separations by carboxymethyl cellulose chromatography. 
RFLPs were found in strong linkage disequilibrium with specific mutations. Since so few of these allele linked polymorphisms have been found to date and since their linkage to the different thalassemia mutations was not absolute, in order to identify whether a fetus has inherited two $\beta$-thalassemia chromosomes it was usually necessary to look for an RFLP linkage by a family study (father, mother and both Grandpas and Grandmas) though it is not often possible to use this approach for prenatal diagnosis.

Due to these problems and to the fact that searching for appropriate polymorphisms within a family and their linkage with the normal and mutant genes is a laborious process the use of this approach for prenatal diagnosis has remained limited. ${ }^{52}$

\section{Oligonucleotide probes}

The molecular background of globin genes defects can be roughly subdivided in two categories, the large deletions and the point mutations. Molecular analysis of large deletions is common for $\alpha$ thalassemia and for some less common $\beta$ thalassemia defects such as $\delta \beta$ thalassemia, and $\gamma \delta \beta$-thalassemia. ${ }^{53,54}$ However, the majority of $\beta$-globin gene defects are point mutations or deletions/insertion of one or two nucleotides. Many of these mutations were recognized using an appropriate DNA probe prepared from the 5' portion of the $\beta$-globin gene. This approach was quite sensitive for the use of a small amount of DNA isolated from fetal material but the main problem was represented by the presence of many mutations that affect $\beta$-globin gene, so it was necessary to perform different tests with specific probes. Furthermore these probes were too long and often it was difficult to detect single base changes that cause many forms of thalassaemia. ${ }^{55}$ Successively an alternative technique was introduced, based on high specific activity labeling short synthetic DNA fragments (oligonucleotides or oligomers) that can hybridize to their homologous sequences but not to heterologous sequences. Upon assay with both the mutant and corresponding mutant synthetic probes, the genotype of an individual with respect to the mutation can be established without reference to additional data. The first works date back to $1980 .^{56-58}$ The latter found that short probes consisting of 19 nucleotides were very efficient to hybridize perfectly with their homologous sequences. The method was sufficiently sensitive to be used with $10 \mathrm{mg}$ or less of DNA per gel lane but careful control of the hybridization and washing conditions was required.

\section{Polymerase chain reaction-based techniques \\ In 1987 it became possible to amplify}

regions of $\beta$-globin directly from genomic DNA.$^{59}$ For the analysis of globin genes in the fetal DNA, it is necessary to perform PCR for the genomic regions in which the mutations previously identified in the parents are located. A number of PCR-based techniques have been developed for the identification of known and unknown mutations of globin genes (Table 1). These techniques included dot-blot (DB) analysis, restriction endonuclease analysis, amplification refractory mutation system (ARMS), reverse dot blot analysis, denaturant gradient gel electrophoresis (DGGE), GAPPCR, sequencing analysis. Each method has got advantages and disadvantages and each laboratory must choose the most suitable mutations present in a specific population. ${ }^{60}$

\section{Restriction enzyme analysis of amplified DNA}

Many $\beta$-thalassemia alleles can be easily identified by restriction enzymes because mutations can create or abolish a restriction endonuclease site altering the normal pattern of digestion fragments visualized after electrophoretic separation on agarose or polycrylamide gel. ${ }^{61}$ If a thalassemic allele does not present a specific restriction endonuclease site it is possible to create an artificial site adjacent to the point mutation during PCR using a primer inserting new bases into amplified product (amplification created restriction sites method). This method was applied to the detection of different $\beta$-thalassemia mutations especially for the second most common mutation in Mediterranean, IVS1 nt 110 defect. ${ }^{2}$

\section{Dot-blot}

The use of amplified DNA and radioactive oligoprobes was one of the first methods used for the detection of known point mutations of $\beta$-globin gene. The principle of dot blot is that a single short strand of DNA (oligonucleotide) methods in relation to the type and variety of

can hybridize to a complementary single strand amplified DNA. This approach requires the immobilization on a nitrocellulose or nylon membrane of amplified DNA target and a single hybridization procedure is performed with one specific oligonucleotide probe labeled at 5 , end with $\gamma^{32}$ ATP. During this procedure any non-specific probe is removed by washing the membrane leaving only the probe that is basepaired to the blotted DNA. Filters are then exposed to X-ray films and results are developed. After removal of radioactive material by washing at $95^{\circ} \mathrm{C}$ in $0.1 \times$ standard saline citrate (SSC) (1 SSC=0.15 M sodium chloride and $0.15 \mathrm{M}$ sodium citrate), $0.1 \%$ sodium dodecyl sulphate, the filters can be subjected to another cycle of hybridization with another probe. For genotyping carrier subject many oligonucleotides are required until the mutation is identified, while for prenatal diagnosis two oligonucleotides probes are necessary for each paternal and maternal mutation or one probe complementary to the normal and one to mutant DNA sequence if the parents have the same mutation.

Although this methodology is adequate and accurate, it is tedious, expensive, and it required a considerable time to identify the mutation(s) in the couples at risk for $\beta$-thalassemia, about $24 \mathrm{~h}$ to screen one mutation and many days to screen the most common mutations present in a specific population. ${ }^{63}$

\section{Reverse dot-blot}

The reverse dot-blot (RDB) was first described by Cai et al., ${ }^{64}$ Saiki et $a l .{ }^{65}$ and successively by Maggio et al.66,67 that used this method to screen $\beta, \alpha$, and $\delta \delta$-globin gene mutations in the Sicilian population. Unlike the dot blot analysis, the reverse dot blot provides the immobilization of oligonucleotide probes on a membrane rather than DNA samples. The advantages of this methodology was that a genomic DNA sample can be amplified

Table 1. Polymerase chain reaction-based techniques for the identification of known and unknown mutations of globin genes.

\begin{tabular}{ll}
\hline Hemoglobinopathies & Techniques \\
$\beta$-thalassemia mutations & Sequencing analysis \\
& ARMS \\
& Reverse dot-blot analysis \\
& GAP-PCR or MLPA ( $\beta$ gene deletion) \\
$\alpha$-thalassemia mutations & Sequencing analysis \\
& GAP-PCR \\
& MLPA \\
\hline$\delta \beta$-thalassemia deletion & GAP-PCR \\
Hb-Lepore & GAP-PCR \\
\hline Hb variants & Sequencing analysis \\
& Restriction enzymatic analysis \\
& ARMS \\
\hline
\end{tabular}

ARMS, amplification refractory mutation system; GAP-PCR, GAP-polymerase chain reaction; MLPA, multiplex ligation-dependent probe amplification. 
and screened simultaneously for a variety of mutations in a working day and that it is nonradioactive method. Unlabeled amino-modified oligonucleotide ASO probes complementary to normal and mutant $\beta$-globin gene alleles are fixed to a nylon membrane strip and hybridized with non-radioactive labeled amplified genomic DNA. During the PCR reaction it is possible to label the DNA by adding biotine16-dUTP instead of d-TTP or using 5' modified primers conjugated with biotine. The protocol requires that the strips be hybridized individually with each denatured amplified DNA samples for about $45 \mathrm{~min}$. The strips are then collectively washed and transferred to a buffer containing avidin alkaline phosphatase for 30 min at room temperature. The color detection is performed using nitroblue tetrazolium salt/5-bromo-4-chloro-3'-indolyphosphate ptoluidine salt. The strategy of RDB is to screen in a single reaction the most common mutations present in a specific population and if no results are obtained one needs to screen for other less common mutations either with a second membrane containing other probes or by direct sequencing. The major advantage of this method is the simultaneous screening of a large number of mutations and the use of nonradioactive material. The most critical point of this assay is the optimization of hybridization conditions and washing temperature for that particular experiment. To date, several commercial kits to screen $\alpha$ and $\beta$ globin gene mutations are still available.

\section{Amplification refractory mutation system}

The amplification refractory mutation system technique is based on the principle that a mismatch at 3' of the PCR primer inhibits the amplification of a target DNA under appropriate conditions. An ARMS reaction for detection of a mutation consists of two couple of primers. One couple is used to screen the presence of the specific mutation while the other couple of primers generate a control amplification product from a different region of the genome under the same condition of PCR. The internal control PCR fragment must be always present indicating that the reaction is working well, while the presence of a mutation is detected by a second fragment generated by the use of primers complementary to the mutated allele. This methodology was used to screen many common and rare mutations by one step reaction. For prenatal diagnosis two separate reactions for each mutation are required, if parents have different mutated alleles, or an ARMS reaction complementary to normal sequence and an ARMS reaction complementary to mutated allele for genotyping fetal DNA if parents have the same mutated allele. This methodology is simple, rapid and inexpensive. ${ }^{68}$

\section{SNaPshot method}

This genotyping technique is a variant of ARMS methodology. The method is based on the principle of single base primer extension to generate an amplified fragment using fluorescent labeling primer visualized on an automated DNA fragment analyzer. More than one known mutation can be screened at the same time in three steps. The first step consists of a multiplex-PCR reaction to generate amplicons including the mutations to screen. The second step consists of a multiplex-PCR single-based extension assay of probe primers using a commercial kit (SNaPshot Kit; Applied Biosystems, Foster City, CA, USA). In this step, DNA polymerase incorporates the complementary dyeconjugated dideoxy nucleotide base at the 3 ' end of each probe primer annealed proximal to the mutations to screen. In the last step, capillary electrophoresis is performed to determine the size of the extended probe primers and fluorescence dye types. The SNaPshot method has already been used for typing Y chromosome and mitochondrial single nucleotide polymorphisms (SNPs) in population analysis and for identifying mutations commonly associated with genetic human pathologies. Usually it is possible to use a common primer for mutations in a restricted zone and a forward or reverse different primer to detect mutations. Primers used as probes are designed to anneal immediately adjacent to the mutated site and their lengths differ from at least five bases by addition to the 5' end of a polyT tail to distinguish them by capillary electrophoresis. This method can be multiplexed to screen many mutations. ${ }^{69}$

\section{GAP-polymerase chain reaction}

GAP-PCR is a simple technique to identify known large gene deletions. Two primers are used complementary to the sense and antisense strand in the DNA regions that flank the deletion. For small deletions, the primer pair will generate two different products, one of which arising from the deleted allele. For larger deletions, the distance between the two flanking primers is too big to amplify the normal allele and the only product obtained is from the deletion allele. In these cases the normal allele is detected by amplifying across one of the deletion breakpoints, using a third primer complementary to part of the deleted sequence near to the flanking normal DNA sequence. This technique is the standard method for diagnosis of the $\mathrm{a}^{+}$deletions defects $\left(-\mathrm{a}^{3.7}\right.$ and $\left.-\mathrm{a}^{4.2}\right)$, the common Mediterranean and Southeast Asian $\mathrm{a}^{0}$-thalassemia deletions (-20.5/aa, — ${ }^{\mathrm{Med}} / \mathrm{aa}, \ldots$ Cal/aa, _ _SEA /aa, _ _ FL/aa, _ _HAI/aa , for diagnosis of triplicated a globin gene alleles (-aaa ${ }^{\text {anti3.7 }}$ and -aaa ${ }^{\text {anti4.2 }}$ ). GAP-PCR is also used to identify common $\delta \beta$-thalassemia alleles (Sicilian,
Turkish, Spanish, Vietnamese, Chinese), Hb Lepore, Hb Kenya deletion and different HPFH deletions (African HPFH 1 and 2, Indian HPFH3). ${ }^{70-74}$

\section{Multiplex ligation-dependent probe ampli-} fication

Although more than $90 \%$ of the deletion defects can be detected using GAP-PCR, other methods are necessary to identify unknown, very rare or very large deletions. Multiplex ligation-dependent probe amplification (MLPA) is a new high-resolution method to detect deletions in genomic sequences. The technique consists of two oligonucleotides that can be ligated to each other when hybridized to a target sequence. All ligated probes have identical sequences at their 5' and 3' ends, permitting simultaneous and quantitative amplification in a PCR containing only one primer pair. Each probe gives rise to an amplification product of unique size. Due to the fluorescent labeling of the primer the resulting products could be separated according to size using capillary electrophoresis system. Fragments are analyzed by specific programs. Peak heights are compared with control sample and ratios are calculated. MLPA has rapidly gained acceptance in genetic diagnostic laboratories due to its simplicity compared to other methods, relatively low cost, capacity for reasonably high throughput and robustness. ${ }^{75,76}$

\section{DNA sequencing}

Sequencing analysis was first developed in 1976-1977 by Maxam and Gilbert using a chemical modification of DNA. ${ }^{77}$ Two years later Sanger and Coulson described a new sequencing method based on in vitro synthesis of DNA from amplified products. ${ }^{78}$ This technology became more popular because it is more efficient than the first method and do not use toxic chemicals and lower amounts of radioactivity. Initially genomic DNA was fragmented into random pieces, cloned into a DNA vector and amplified in Escherichia coli. Short DNA fragments purified from individual bacterial colonies are individually sequenced and assembled electronically into one long, contiguous sequence. The classical chain-termination method requires a single-stranded DNA template, a DNA primer, a DNA polymerase, normal deoxynucleotidetriphosphates (dNTPs) and modified nucleotides (dideoxy NTPs) that terminate DNA strand elongation. Initially, radioactive labeled probe was used. The DNA sample is divided into four separate sequencing reactions, containing all four of the standard deoxynucleotides (dATP, dGTP, dCTP and dTTP) and the DNA polymerase. To each reaction is added only one of the four dideoxynucleotides (ddATP, ddGTP, ddCTP, or ddTTP) which are the specific chain-terminating nucleotides, lacking a 3'-OH group 
required for the formation of a phosphodiester bond between two nucleotides, thus terminating DNA strand extension and resulting in DNA fragments of varying length. The newly synthesized and labeled DNA fragments are heat denatured, and separated by size (with a resolution of just one nucleotide) by gel electrophoresis on a denaturing polyacrylamideurea gel in four separated lanes (lanes A, T, G, C); the DNA bands are then visualized by autoradiography or UV light and the DNA sequence can be directly read off the X-ray film or gel image. More recently methods, which allow sequencing in a single reaction, rather than in four, have been developed. In dye-terminator sequencing, each of the fourdideoxynucleotide chain terminators is labeled with fluorescent dyes, each of which emits light at different wavelengths. Fluorescent peaks chain-termination methods have greatly simplified DNA sequencing. Chain-termination-based kits are commercially available that contain the reagents needed for sequencing, pre-aliquoted and ready to use. As globin genes are relatively short, about 2000 bases, it is possible to sequence each gene using 2-3 amplified fragments by cycle sequencing analysis in few days. This method is very rapid and easy permitting the direct check of all sequence of the gene without the use of radioactive labels. A relative disadvantage is the cost of a sequencing instrument and sequencing signal deterioration after $800-1000$ bases. $^{79}$

\section{Denaturant gradient gel electrophoresis}

Myers et al. ${ }^{80}$ in 1986 described a technique, which uses heteroduplex formation between wild type and mutated DNA strands to identify mutations. When a DNA fragment is analyzed by electrophoresis through a linearly increasing gradient of denaturants, the fragment remains double stranded until it reaches the concentration of denaturants equivalent to a melting temperature (Tm) that causes the partial melting of lower-Tm domains fragment. At this point, the branching of the molecule caused by partial melting sharply decreases the mobility of the fragment in the gel. The lower-temperature melting domains of DNA fragments differing by as little as a single-base substitution will melt at slightly different denaturant concentrations because of differences in stacking interactions between adjacent bases in each DNA strand. These differences in melting cause two DNA fragments to begin slowing down at different levels in the gel, resulting in their separation from each other.

Although DGGE can identify a mutant, it does not reveal the nature or exact location of the mutation but this information can be revealed by sequencing analysis.

DGGE can detect mutations only in the lower temperature melting domains, so it is important to determine what portion of the molecule becomes single stranded when the DNA melts. This fact can be determined by use of a computer algorithm, developed by $\mathrm{L}$. Lerman that predicts DNA melting behavior solely from the base-pair sequence. However, DGGE will not separate DNA fragments differing by a base change in the highest temperature-melting domain due to loss of sequencedependent gel migration upon complete strand separation. To permit the detection of point mutations along the complete amplified fragment of the gene under analysis, a GC-rich segment of 30-60 bases may be attached to the 5 ' of one primer of the pair. This tail has a high $\mathrm{Tm}$ and the DNA fragment has a lower $\mathrm{Tm} .{ }^{81,82}$

\section{Denaturing high-pressure liquid chromatography}

Denaturing high-pressure liquid chromatography (DHPLC) is a relatively new technique analogous to DGGE. Heteroduplex molecules are separated from homoduplex molecules by ion-pair, reverse-phase liquid chromatography on a special column matrix with partial heat denaturation of the DNA strands.

The method is based on the different retention time of homoduplex and eteroduplex molecules within a mixture of denatured and reannealed DNA fragments. Heteroduplex molecules have a retention time lower than the correspondent homoduplex molecule and the eluted DNA fragment is detected by UV. This is a semi-automated method and, maintaining the HPLC column at a temperature that favors partial strand denaturation in the presence of base-pair mismatching, maximizes the sensitivity of the analysis. The vantages of DHPLC are that it has high specificity and sensitivity and has low running costs. However, the method is not suitable for direct analysis of homozygous samples since the DNA must be mixed with a reference of a known genotype prior analysis. DHPLC is potentially a very useful method for the screening of a large number of samples. ${ }^{83-86}$

\section{Best practice for molecular prenatal diagnosis of hemoglobinopathies}

In order to reduce the occurrence of misdiagnoses, some fundamental strategies and methodologies are introduced in the laboratory procedures: i) analysis of two different pieces of chorionic villus; ii) test to rule out maternal contamination or non-paternity or sample exchange. It is advisable to analyze both DNA extracts and analysis should be conducted by two different operators using different methodologies. It is strongly recommended that, in addition to screening for parental mutations, prenatal diagnosis should include maternal cell contamination test. The potential presence of maternal contamination in CVS or amniotic fluid samples is the main risk in prenatal diagnosis when sensible PCR-based methods are used. The effect of contamination, after CVS, can be limited by careful dissection of maternal decidua. Amniotic fluid can be contaminated with maternal blood and this is easily visible because the sample appears bloodstained. It is to be put in evidence that the blood in amniotic fluid can also be of fetal in origin. For these reasons it is necessary to use sensitive assays and very polymorphic microsatellite markers by quantitative fluorescent polymerase chain reaction (QFPCR). Best practice requires also the analysis of both maternal and paternal samples. Naturally, clinicians should inform the couple that this test might reveal non-paternity or de novo mutations. ${ }^{87-89}$

\section{Prenatal diagnosis earlier in pregnancy}

Although CVS can be undertaken earlier, recent concern over the risks of miscarriage and limb defects has restricted the use of CVS to 11 weeks and beyond. ${ }^{90-92}$ Early amniocentesis has been associated with pulmonary hypoplasia and the low number of cells obtained often makes definitive diagnosis difficult. In addition, the relative safety of early amniocentesis is lower than CVS. ${ }^{93,94}$ Inherent problems with current prenatal diagnosis, coupled with benefits of earlier reassurance or termination, would make an alternative earlier method very valuable. At days 11 and 12 postconception, a new population of cells appears between the inner surface of the cytotrophoblast and the membrane which lines the primary yolk sac (Heuser's membrane). ${ }^{95}$ These cells, which are derived from the yolk sac, form a fine, loose connective tissue, the extraembryonic mesoderm, which eventually fills all the space between the trophoblast externally and the amnion and Heuser's membrane internally (Figure 3). The coelomic or extraembryonic cavity develops during the fourth week of gestation, within the extraembryonic mesoderm that surrounds the bilaminar embryonic disk. The developing coelomic cavity splits the extraembryonic mesoderm in two layers, the somatic and splanchnic mesoderm. ${ }^{96}$ During the first nine weeks of gestation the coelomic cavity represents the largest space inside the gestational amniotic cavity reaching maximum volume at 7-9 weeks, then subsequently disappearing at around 13 weeks. The advent of high-resolution transvaginal ultrasound transducers allowed a more accurate examination of the early pregnancy. The visualization of the membranes separating the amniotic and coelomic cavity made possible the selective aspiration of coelomic fluid from as early as five weeks gestation. Examination of the fluid demonstrated that although cells from the exocoelomic cavity 
cannot be successfully cultured, embryonic genetic material could be analyzed using PCR techniques. $^{97}$

\section{Sampling}

The coelomatic fluid can be sampled at 7-9 weeks gestation by transvaginal sonography by insertion of $20 \mathrm{G}$ needle through the vagina into the coelomic cavity ${ }^{98}$ Debates on the safety of coelocentesis are however ongoing. Ross et al. ${ }^{99}$ observed that coelocentesis is associated with a high rate of miscarriage; they reported a $25 \%$ fetal loss rate within 2-3 days following coelocentesis. This author reports that the difficulty for the aspiration of coelomic fluid may require an increased number of multiple punctures further compromising the safety. Santolaya-Forgas et al., ${ }^{100}$ examining the safety of coelocentesis in baboons, reported that this procedure might be safe for the pregnancy if it is performed at about 40 days of gestation using a $20 \mathrm{G}$ needle and if less than $3 \mathrm{~mL}$ of coelomic fluid is aspirated. In another study, Ross et al. ${ }^{99}$ reported the results of coelocentesis in 107 women and 337 controls, showing that the risk of fetal loss between 7 and 9 weeks of gestation is about $2 \%$, and comparable to the fetal loss following CVS.

Coelomic fluid characteristics and limitations for prenatal diagnosis by coelocentesis

As reported by different authors, coelomic fluid contains fetal cells. ${ }^{97}$ These cells have been initially used to determine fetal sex, sickle cell disease (SCD) ${ }^{101}$ and other single-gene defects but often a diagnosis was impossible for high rate of maternal contamination. The main problems encountered during prenatal diagnosis using $\mathrm{CF}$ are the following:

The number of fetal cells. Jouannic et al. ${ }^{102}$ reported a variable number of the cellular count from complete absence to more than $10,000 \mathrm{cells} / \mathrm{mL}$. We observed in our studies. a variable number of cells but at least 15-20 fetal cells were always present in $1 \mathrm{~mL}$ of coelomic fluid.

Therefore, Jouannica et al. reported that the amount of total DNA in the CF was very low and variable, often insufficient. The total concentration of amplified DNA using a real-time PCR assay ranged from undetectable to $777.5 \mathrm{ng} / \mathrm{mL}$ (median: 17.9 $\mathrm{ng} / \mathrm{mL}) .^{103}$

It has been suggested that coelomic cells may arise from the villous mesenchymal core or from the yolk sac including hematopoietic progenitors. However, the precise cellular origin of this fluid remains unknown. ${ }^{104}$ Nevertheless, Renda et al., ${ }^{105}$ demonstrated that most of fetal cells in the coelomatic fluid were functional embryonic erythroid precursors, megaloblasts.

The presence of variable number of maternal and fetal cells in the coelomatic fluid deter- mining contamination was an obstacle to perform prenatal diagnosis. Contamination and subsequent potential misdiagnosis were considered the major risks with any diagnostic system becoming more significant when the number of fetal cells decreases.

In our center we have analyzed more than 100 coelomatic fluids and observed that about $10 \%$ were samples without maternal contamination while about $86 \%$ showed maternal contamination between $10 \%$ and $70 \%$ and $4 \%$ presented maternal contamination in a percentage of more than $70 \%$. The cellular composition of coelomatic fluid has permitted to develop method using antibody to purify the samples. We were able to purify the contaminated samples using anti-CD45 and anti-CD105 MicroBeads (Milteny Biotec, Bergisch Gladbach, Germany) for negative selection, removing the principal cells of maternal origin (white blood cells CD $45^{+}$and mesenchymal/ endothelial cells $\left.\mathrm{CD} 105^{+}\right) .{ }^{15}$

\section{Analysis of coelomatic fetal cells}

In order to establish a suitable protocol, preclinical experiments on coelomatic fluid have been carried out in our laboratory and then validated before voluntary interruption of pregnancy. Despite the difficulties encountered to find the best target cell and the best method for their enrichment and isolation, several attempts have been made in last years to transfer the results of these researches into clinical practice. The problems regarding contamination of coelomic samples suggested that contamination detection should be an integral part of coelomic fluid analysis in a prenatal diagnostic setting. ${ }^{106}$ The parallel analysis of

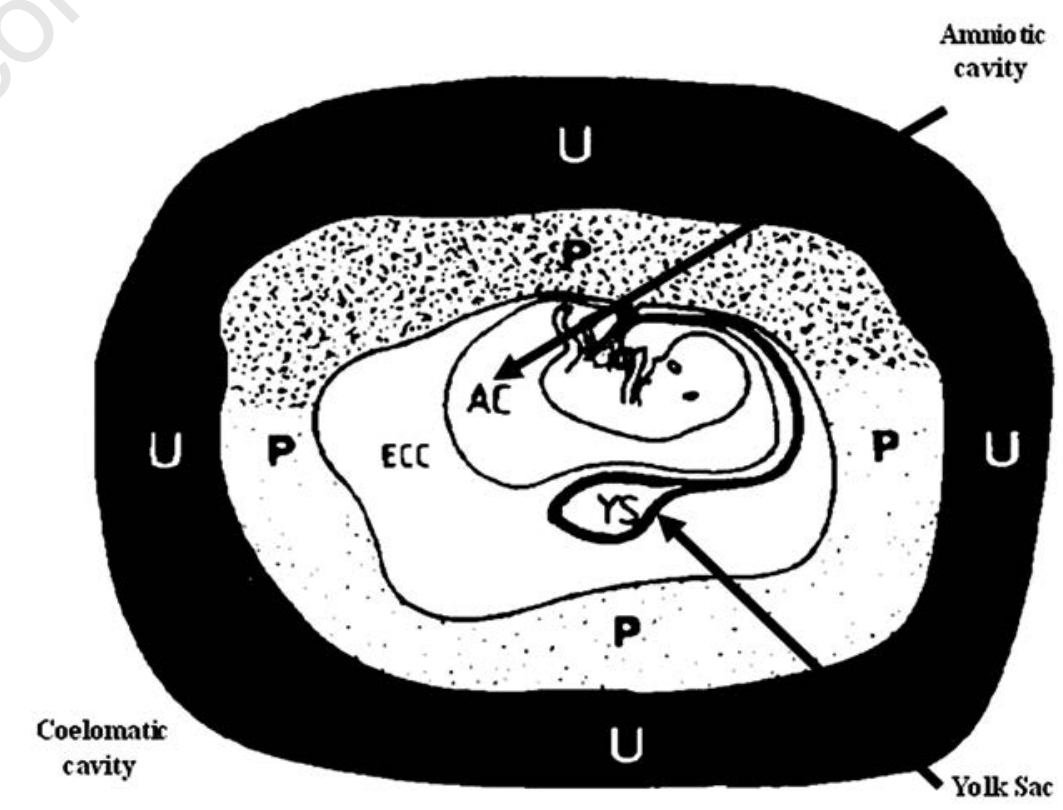

Figure 3. Coelomatic cavity. microsatellite allele sizes compared to those of parents is strongly recommended to check the presence of maternal contamination (Figure 4). Giambona et al. ${ }^{15}$ suggested that at 7-9 weeks the use of protocols involving fluorescently labeled amplicons are also recommended since they are much more sensitive for low DNA copy numbers and QF-PCR is a suitable technique for detection of maternal contamination in celomatic fluid. In addition, it is recommend the analysis of polymorphic markers linked to the disease-causing locus gene in the same amplified fragment containing point mutation in order to support the accuracy of the genotyping result.

\section{Laboratory method}

More than 100 prenatal diagnoses for hemoglobinopathies have been performed in our lab using coelomatic fluid. ${ }^{15}$ After one insertion of a $20 \mathrm{G}$ needle in the coelomatic cavity, three samples of coelomatic fluid were aspirated into different syringes $(0.2,0.2,0.6 \mathrm{~mL})$. The first two samples are usually discarded because of high chance of maternal contamination while the third sample is analyzed. Fifty $\mu \mathrm{L}$ of the third sample is first used to evaluate the presence and the percentage of maternal contamination by QF-PCR. If maternal cells are absent or in a percentage lower than $10 \%$, the all of the sample is lysated and the $\beta$-globin gene is analyzed by direct sequencing. In case of higher contamination (more than 10\%) the entire third sample is purified using anti-CD45 and anti-CD105 MicroBeads (Miltenyi Biotec). Eventual trace of maternal contamination is evaluated by QF-PCR after selection of mater- 
nal cells and $\beta$-globin gene is analyzed by the direct sequencing or for linkage analysis with polymorphic sites in the same amplified segment of the $\beta$-globin gene. ${ }^{15}$

\section{Non-invasive prenatal diagnosis}

The possibility to perform noninvasive DNA tests on the fetus, avoiding risk of fetal loss due to invasive procedures, was always searched. Both fetal cells and free fetal DNA provide the development of protocols for noninvasive prenatal diagnosis (NIPD) of single gene disorders (and chromosome abnormalities in the case of fetal cells). From the $1960 \mathrm{~s}$ a variety of approaches were investigated for the isolation of fetal nucleated cells from maternal plasma, but the complexity of the cell isolation process (due also to the low amount) and the lack of reproducibility preclude the use of this approach in clinical practice. ${ }^{107}$

Likewise, many studies have been performed to make NIPD by analysis of free fetal DNA (ffDNA) in the maternal blood circulation. This has been applied successfully for fetal sex determination, RhD genotype and trisomy 21 detection; cell-free fetal DNA is detectable very early during pregnancy and the average amount of cell ffDNA during the first and the second trimesters is $\sim 10 \%$ of the total amount of cell-free DNA. ${ }^{108}$ Recently it was developed a method for NIPD of $\beta$-thalassemia major and SCD that combine pyrophosphorolysis-activated polymerization (PAP) assay and melting curve analysis (MCA); PAP is able to detect mutations in free fetal DNA in a highly contaminating environment of maternal plasma, while MCA is a helpful screening method to identify which of the SNPs are informative in the family. In contrast to other methods used for NIPD, the combined PAP and MCA analysis detecting the normal paternal allele is also applicable for couples at risk carrying the same mutation, provided that a previously born child is available for testing to determine the linkage to the paternal SNPs. ${ }^{108}$

\section{Preimplantation and preconcep- tional genetic diagnosis}

Preimplantation and preconceptional genetic diagnosis (PGD) is an established reproductive alternative prenatal diagnosis, offered in quite a number of specialized centers throughout the world. It is used for monogenic diseases or known chromosomal disorders and can be applied for any genetic disease for which there is enough sequence information to facilitate the design of specific primers or probes. Preimplantation genetic diagnosis is performed either by biopsy of one to two blastomers in eight-cell embryos after in vitro fertilization or by biopsy of tro- phectoderm cells from blastocyst. PGD is based on the analysis of the first polar body of unfertilized eggs followed by analysis of the second polar bodies after fertilization, which is performed to avoid misdiagnosis resulting from recombination during the first meiosis; diagnosis is obtained by multiplex nested PCR analysis to detect the mutations as well as polymorphic alleles at the $\beta$-globin gene cluster. ${ }^{107}$

\section{Conclusions}

Advanced imaging techniques as well as molecular biology methods have opened up new perspectives in prenatal diagnoses for hemoglobinopathies and for a number of severe hereditary disorders. Improvements include anticipating the diagnosis earlier in pregnancy and decreasing the diagnostic time

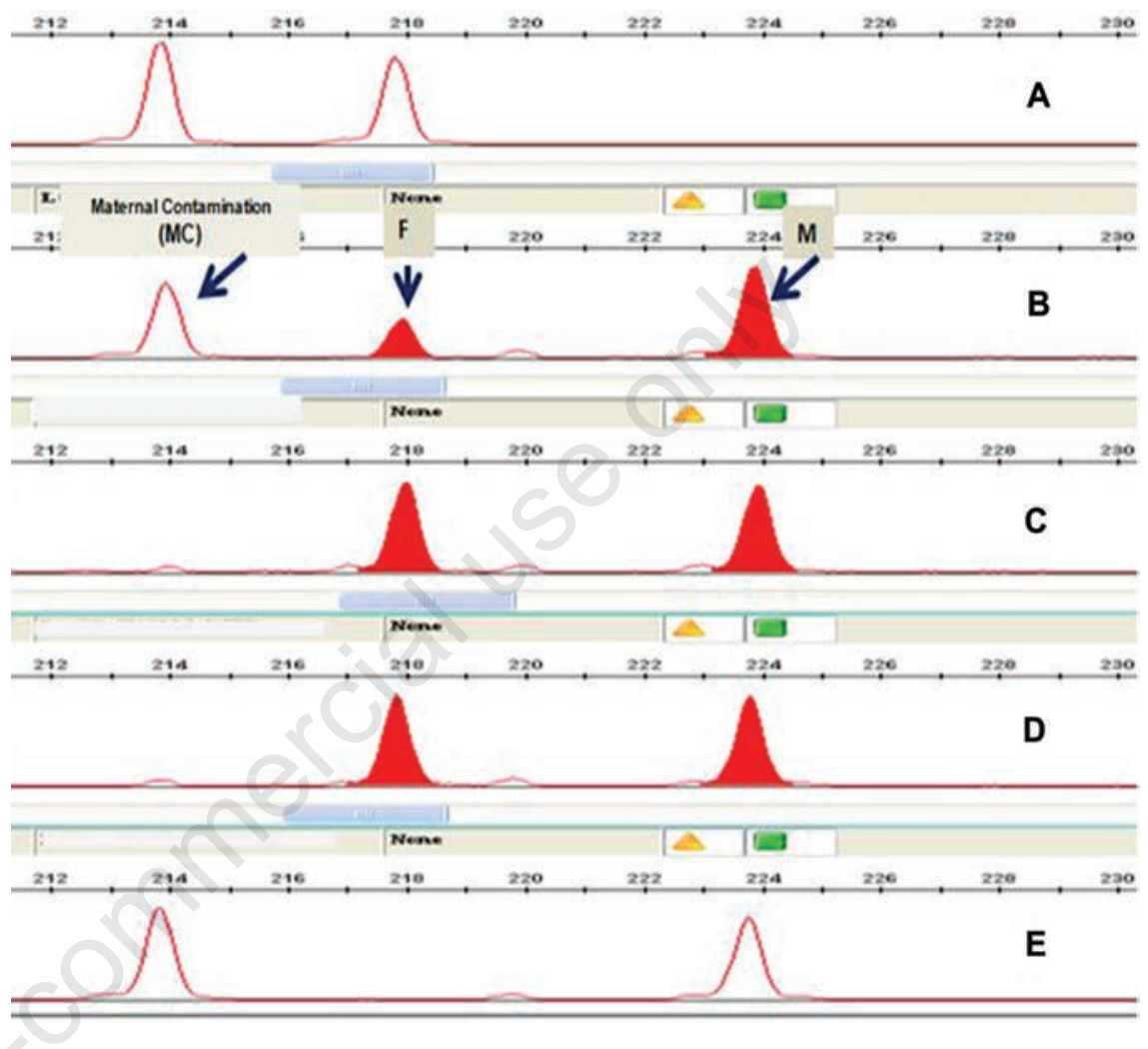

Figure 4. Contamination control by parents' alleles quantitative fluorescent polymerase chain reaction valuation: A) father; B) coelomatic fluid before antibodies selection; C) coelomatic fluid after antibodies selection using anti-CD45 and anti-CD105 for negative selection; D) amniotic fluid; E) mother.

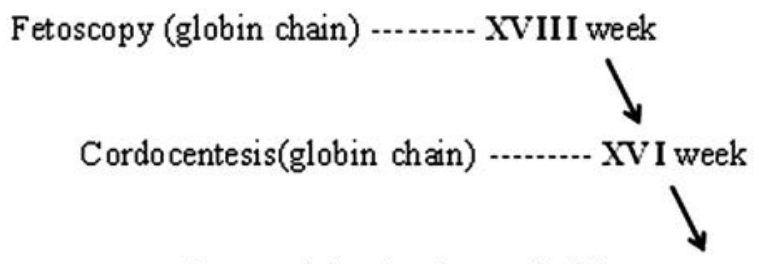

Amniocentesi (molecular analysis) -...-. XVI week Villocentesi (molecular analysis) ....... XI week

Coelocentesis (molecular analysis) -...-.-VII-IX weeks

Figure 5. Progress in prenatal diagnosis of hemoglobinopathies. 
and risk (Figure 5).

Standard methods, based on molecular techniques, require a few days and very small sample of fetal material. The ideal prenatal diagnostic method should have three important characteristics: i) diagnostic accuracy; ii) fetal and maternal safety; and iii) widespread applicability. Non-directive but thorough genetic counseling is essential in association with prenatal diagnosis procedures and with information and carrier screening one of the pillars of prevention of genetic diseases. Understand the severity of the disease, the details of fetal analysis used for prenatal diagnosis (feasibility, risk for the fetus, failure and eventually misdiagnosis). Parents should be able to take a well-informed reproductive decision in the event that the fetus would results affected. ${ }^{109}$ The woman or the couple should take a decision according to their moral and/or religious feelings of responsibility. Religious leaders may opposed abortion of severely affected children or consider it as an act of mercy while public health authorities may consider it a valid alternative to reduce human suffering and public health expenses. ${ }^{110,111}$ In several Muslim countries abortion is permissible up to 120 days of gestation to save the life of the mother or to prevent a severely affected child, while, for example, in Morocco, a land with very high illegal abortions, the intervention is punished by law unless the mother's life is in danger. ${ }^{112,113}$ Furthermore, people who have made a decision should be help and they should not be discriminated for their decision either terminating the pregnancy or giving birth to an affected child. If the pregnancy has to be continued it should be provide best possible medical care after birth. Furthermore, the couple at risk should be informed about the possibility to carry out HLA typing on fetal DNA to assess whether a previous normal or heterozygous children is HLA-identical and suitable for bone marrow transplantation. Coelocentesis might be a realistic alternative to the standard prenatal invasive procedures. The reliability of this procedure was $96 \%$ and ongoing study will increase the feasibility even in the case that the sample of coelomatic fluid is very poor of fetal cells, whereas the accuracy was $100 \%$, without any discordance between results obtained by coelomatic fluid and controls by amniocentesis or on abortive tissue. Analysis is rapid and in one-day work it is possible to obtain results of prenatal diagnosis.

\section{References}

1. Weatherall DJ, Clegg JB. The thalassemia syndromes. 4th ed. Oxford: Blackwell Scientific Pubblication; 2008.

2. Cao A, Gossens M, Pirastu M. $\beta$ thalas- saemia mutations in Mediterranean populations. Br J Haematol 1989;71:309-12.

3. Hill AV. Molecular epidemiology of the thalassaemias (including haemoglobin E). Baillieres Clin Haematol 1992;5:209-38.

4. Haj Khelil A, Denden S, Leban N, et al. Hemoglobinopathies in North Africa: a review. Hemoglobin 2010;34:1-23.

5. Modell B, Darlison M, Birgens H, et al. Epidemiology of haemoglobin disorders in Europe: an overview. Scand J Clin Lab Invest. 2007;67:39-69.

6. Weatherall DJ. Thalassemia as a global health problem: recent progress toward its control in the developing countries. Ann N Y Acad Sci 2010;1202:17-23.

7. Angastiniotis MA, Hadjiminas MG. Prevention of thalassaemia in Cyprus. Lancet. 1981;1:369-71.

8. Cao A, Furbetta M, Galanello R, et al. Prevention of homozygous $\beta$-thalassemia by carrier screening and prenatal diagnosis in Sardinia. Am J Med Genet 1981;33: 592-605.

9. Cao A, Rosatelli MC. Screening and prenatal diagnosis of the haemoglobinopathies. Baillieres Clin Haematol 1993;6:263-86.

10. Clarke GM, Higgins TN. Laboratory investigation of hemoglobinopathies and thalassemias: review and update. Clin Chem 2000;46:1284-90.

11. Giambona A, Passarello C, Renda D, et al. The significance of the hemoglobin A2 value in screening for hemoglobinopathies. Clin Biochem 2009;42:1786-96.

12. Cao A. Carrier screening and genetic counselling in $\beta$-thalassemia. Int $\mathrm{J}$ Hematol 2002;76:105-13.

13. Makrydimas G, Georgiou I, Kranas V, et al. Prenatal diagnosis of $\beta$-thalassaemia by coelocentesis. Mol Hum Reprod 1997;3: 729-31.

14. Daffos F, Capella-Pavlovsky M, Forestier F. Direct collection of fetal blood from the umbilical vein under echography. First results, prospects. Presse Med 1983; 12:1017.

15. Giambona A, Makrydimas G, Leto F, et al. Feasibility of DNA diagnosis of haemoglobinopathies on coelocentesis. $\mathrm{Br} \mathrm{J}$ Haematol 2011;153:268-72.

16. Alter BP, Modell CB, Fairweather D, et al. Prenatal diagnosis of hemoglobinopathies. A review of 15 cases. N Engl J Med 1976;295:1437-43.

17. Old JM, Ward RH, Petrou M, et al. First Trimester fetal diagnosis of haemoglobinopathies: three cases. Lancet 1982:2:1413-6.

18. Orkin SH. Prenatal diagnosis of hemoglobin disorders by DNA analysis. Blood 1984;63:249-53.

19. Antonarakis SE, Phillips JA 3rd, Kazazian HH Jr. Genetic diseases: diagnosis by restriction endonuclease analysis. J Pediatr 1982;100:845-56.

20. Pirastu M, Kan YW, Cao A, et al. Prenatal diagnosis of $\beta$-thalassemia. Detection of a single nucleotide mutation in DNA. N Engl J Med 1983;309:284-7.

21. Saiki RK, Bugawan TL, Horn GT, et al. Analysis of enzymatically amplified $\beta$-globin and HLA-DQ $\alpha$ DNA with allele-specific oligonucleotide probes. Nature 1986;324:163-6.

22. Kan YW, Nathan DG, Lodish HF. Equal synthesis of $\alpha$ - and $\beta$-globin chains in erythroid precursors in heterozygous -thalassemia. J Clin Invest 1972;51:1906-9.

23. Gaburro D, Volpato S, Vigi V. Diagnosis of $\beta$ thalassaemia in the newborn by means of haemoglobin synthesis. Acta Paediatr Scand 1970;59:523-8.

24. Alter BP, Kan YW, Nathan DG. Reticulocyte survival in sickle cell anemia: effect of cyanate. Blood. 1972;40:733-9.

25. Chang H, Hobbins JC, Cividalli G, et al. In utero diagnosis of: hemoglobinopathies. Hemoglobin synthesis in fetal red cells. N Engl J Med 1974;290:1067-8.

26. Hobbins JC, Mahoney MJ. In utero diagnosis of hemoglobinopathies. Technic for obtaining fetal blood. N Engl J Med 1974;290:1065-7.

27. Kan YW, Valenti C, Carnazza V, et al. Fetal blood-sampling in utero. Lancet 1974;1:79-80.

28. Rodeck CH. Fetoscopy in prenatal diagnosis. Midwife Health Visit Community Nurse 1978;14:421-3.

29. Hobbins JC, Mahoney MJ, Goldstein LA. New method of intrauterine evaluation by the combined use of fetoscopy and ultrasound. Am J Obstet Gynecol 1974;118: 1069-72.

30. Rodeck CH, Campbell S. Sampling pure fetal blood by fetoscopy in second trimester of pregnancy. Br Med J 1978;2: 728-30.

31. Fairweather DV, Ward RH, Modell B. Obstetric aspects of midtrimester fetal blood sampling by needling or fetoscopy. Br J Obstet Gynaecol 1980;87:87-99.

32. Betke K, Kleihauer E. Fetal and residual hemoglobin in the erythrocytes and erythroblasts of human fetuses and newborn infants. Blut 1958;4:241-9.

33. Alter BP, Metzger JB, Yock PG, et al. Selective hemolysis of adult red blood cells: an aid to prenatal diagnosis of hemoglobinopathies. Blood 1979;53:279-87.

34. Oski FA. Fetal hemoglobin, the neonatal red cell, and 2,3-diphosphoglycerate. Pediatr Clin North Am 1972;19:907-17.

35. Fairweather DV, Modell B, Berdoukas V, et al. Antenatal diagnosis of thalassaemia major. Br Med J 1978;1:350-3.

36. Kan Y, Nathan DG, Cividalli G, et al. Concentration of fetal red blood cells from 
a mixture of maternal and fetal blood by anti-i serum - an aid to prenatal diagnosis of hemoglobinopathies. Blood 1974;43: 411-5.

37. Furbetta M, Valenti C, Ximenes A, et al. Prenatal diagnosis of $\beta$-thalassaemia by fetal red cell concentration with anti-AB serum. J Med Genet 1979;16:366-8.

38. Alter BP, Modell CB, Fairweather D, et al. Prenatal diagnosis of hemoglobinopathies. A review of 15 cases. N Engl J Med 1976;295:1437-43.

39. Boyer SH, Noyes AN, Boyer ML. Enrichment of erythrocytes of fetal origin from adult-fetal blood mixtures via selective hemolysis of adult blood cells: an aid to antenatal diagnosis of hemoglobinopathies. Blood 1976;47:883-97.

40. Clegg JB, Weatherall DJ, Na-Nakorn S, et al. Haemoglobin synthesis in $\beta$-thalassaemia. Nature 1968;220:664-8.

41. Cividalli G, Nathan DG, Kan YW, et al. Relation of $\beta$ to $\gamma$ synthesis during the first trimester: an approach to prenatal diagnosis of thalassemia. Pediatr Res 1974;8:55360.

42. Cao A, Furbetta M, Angius A, et al. Haematological and obstetric aspects of antenatal diagnosis of $\beta$-thalassaemia: experience with 200 cases. J Med Genet 1982;19:81-7.

43. Loukopoulos D, Antsaklis A, AleporouMarinou V, et al. Prenatal diagnosis of $\beta$ thalassemia; the greek experience. Birth Defects Orig Artic Ser 1982;18:293-301.

44. Congote LF, Hamilton EF, Chow JC, et al. Prenatal diagnosis of hemoglobinopathies: evaluation of techniques for analysing globin-chain synthesis in blood samples obtained by fetoscopy. Can Med Assoc J 1982;127:843-9.

45. Orkin SH. Prenatal diagnosis of hemoglobin disorders by DNA analysis. Blood 1984;63:249-53.

46. Phillips JA 3rd. Prenatal diagnosis of sickle cell anemia and $\beta$-thalassemia by amniocentesis. Tex Rep Biol Med 19801981;40:261-72.

47. Williamson R, Eskdale J, Coleman DV, et al. Direct gene analysis of chorionic villi: A possible technique for first-trimester antenatal diagnosis of haemoglobinopathies. Lancet 1981;2:1125-7.

48. Miller SA, Dykes DD, Polesky HF. A simple salting out procedure for extracting DNA from human nucleated cells. Nucleic Acids Res 1988;16:1215.

49. Southern EM. Detection of specific sequences among DNA fragments separated by gel electrophoresis. J Mol Biol 1975;98:503-17.

50. Old JM, Ward RH, Petrou M, et al. Firsttrimester fetal diagnosis for haemoglobinopathies: three cases. Lancet
1982;2:1413-6.

51. Kan YW, Dozy AM. Polymorphism of DNA sequence adjacent to human $\beta$-globin structural gene: relationship to sickle mutation. Proc Natl Acad Sci U S A 1978;75:5631-5.

52. Kan YW, Lee KY, Furbetta M, et al. Polymorphism of DNA sequence in the $\beta$ globin gene region. Application to prenatal diagnosis of $\beta 0$ thalassemia in Sardinia. N Engl J Med 1980;302:185-8.

53. Ottolenghi S, Comi P, Giglioni B, et al. $\Delta$ $\beta$-thalassemia is due to a gene deletion. Cell 1976;9:71-80.

54. Labie D. Genetics and structure of hemoglobin lepore. Folia Haematol Int Mag Klin Morphol Blutforsch 1968;90:110-6.

55. Cao A, Cossu P, Monni G, et al. Prenatal diagnosis of $\beta$ thalassaemia by oligonucleotide analysis in Mediterranean populations. Prenat Diagn 1987;7:531-3.

56. Liebhaber SA, Trecartin RF, Kan YW. B thalassemia in Sardinia in the result of a nonsense mutation. Trans Assoc Am Physicians 1981;94:88-96.

57. Higgs DR, Goodbourn SE, Wainscoat JS, et al. Highly variable regions of DNA flank the human $\alpha$ globin genes. Nucleic Acids Res 1981;9:4213-24.

58. Weatherall DJ, Old JM, Thein SL, et al. Prenatal diagnosis of the common haemoglobin disorders. J Med Genet 1985;22:42230 .

59. Saiki RK, Gelfand DH, Stoffel S, et al. Primer-directed enzymatic amplification of DNA with a thermostable DNA polymerase. Science 1988;239:487-91.

60. Giambona A, Vinciguerra M, Cannata M, et al. The genetic heterogeneity of $\beta$-globin gene defects in Sicily reflects the historic population migrations of the island. Blood Cells Mol Dis 2011;46:282-7.

61. Lindeman R, Wallace R, Volpato F, et al. Utility of the polymerase chain reaction (PCR) for prenatal diagnosis of genetic disease. Pathology 1991;23:158-63.

62. Lindeman R, Hu SP, Volpato F, et al. Polymerase chain reaction (PCR) mutagenesis enabling rapid non-radioactive detection of common $\beta$-thalassaemia mutations in Mediterraneans. $\mathrm{Br} \mathrm{J}$ Haematol 1991;78:100-4.

63. Kafatos FC, Jones CW, Efstratiadis A. Determination of nucleic acid sequence homologies and relative concentrations by a dot hybridization procedure. Nucleic Acids Res 1979;7:1541-52.

64. Cai SP, Chang CA, Zhang JZ, et al. Rapid prenatal diagnosis of $\beta$ thalassemia using DNA amplification and nonradioactive probes. Blood 1989;73:372-4.

65. Saiki RK, Walsh PS, Levenson $\mathrm{CH}$, et al. Genetic analysis of amplified DNA with immobilized sequence-specific oligonu- cleotide probes. Proc Natl Acad Sci U S A 1989;86:6230-4.

66. Maggio A, Giambona A, Cai SP, et al. Rapid and simultaneous typing of hemoglobin $\mathrm{S}$, hemoglobin $\mathrm{C}$, and seven Mediterranean $\beta$-thalassemia mutations by covalent reverse dot-blot analysis: application to prenatal diagnosis in Sicily. Blood 1993;81:239-42.

67. Foglietta E, Bianco I, Maggio A, et al. Rapid detection of six common Mediterranean and three non-Mediterranean $\alpha$-thalassemia point mutations by reverse dot blot analysis. Am J Hematol 2003;74:191-5.

68. Old JM, Varawalla NY, Weatherall DJ. Rapid detection and prenatal diagnosis of $\beta$-thalassaemia: studies in Indian and Cypriot populations in the UK. Lancet 1990;336:834-7.

69. Pastinen T, Kurg A, Metspalu A, et al. Minisequencing: a specific tool for DNA analysis and diagnostics on oligonucleotide arrays. Genome Res 1997;7:606-14.

70. Craig JE, Barnetson RA, Prior J, et al. Rapid detection of deletions causing $\delta \beta$ thalassemia and hereditary persistence of fetal hemoglobin by enzymatic amplification. Blood 1994;83:1673-82.

71. Bowden DK, Vickers MA, Higgs DR. A PCRbased strategy to detect the common severe determinants of $\alpha$ thalassaemia. $\mathrm{Br}$ J Haematol 1992;81:104-8.

72. Winichagoon P, Fucharoen S, Kanokpongsakdi $S$, et al. Detection of $\alpha$-thalassemia-1 (Southeast Asian type) and its application for prenatal diagnosis. Clin Genet 1995;47:318-20.

73. Chong SS, Boehm CD, Cutting GR, et al. Simplified multiplex-PCR diagnosis of common southeast asian deletional determinants of $\alpha$-thalassemia. Clin Chem 2000;46:1692-5.

74. Liu YT, Old JM, Miles K, et al. Rapid detection of $\alpha$-thalassaemia deletions and $\alpha$ globin gene triplication by multiplex polymerase chain reactions. Br J Haematol 2000;108:295-9.

75. Harteveld CL, Refaldi C, Cassinerio E, et al. Segmental duplications involving the $\alpha$-globin gene cluster are causing $\beta$-thalassemia intermedia phenotypes in $\beta$-thalassemia heterozygous patients. Blood Cells Mol Dis 2008;40:312-6.

76. Nezhat N, Akbari MT. Detection of deletions/duplications in $\alpha$-globin gene cluster by multiplex ligation-dependent probe amplification. Genet Test Mol Biomarkers 2012;16:684-8.

77. Maxam AM, Gilbert W. A new method for sequencing DNA. Proc Natl Acad Sci U S A 1977;74:560-4.

78. Sanger F, Nicklen S, Coulson AR. DNA sequencing with chain-terminating inhibitors. Proc Natl Acad Sci U S A 
1977;74:5463-7.

79. Swerdlow H, Gesteland R. Capillary gel electrophoresis for rapid, high resolution DNA sequencing. Nucleic Acids Res 1990; 18:1415-9.

80. Myers RM, Maniatis T. Recent advances in the development of methods for detecting single-base substitutions associated with human genetic diseases. Cold Spring Harb Symp Quant Biol 1986;51:275-84.

81. Sheffield VC, Cox DR, Lerman LS, et al. Attachment of a 40-base-pair G + C-rich sequence (GC-clamp) to genomic DNA fragments by the polymerase chain reaction results in improved detection of single-base changes. Proc Natl Acad Sci U S A 1989;86:232-6.

82. Harteveld KL, Heister AJ, Giordano PC, et al. Rapid detection of point mutations and polymorphisms of the $\alpha$-globin genes by DGGE and SSCA. Hum Mutat 1996;7:11422. Erratum in: Hum Mutat 1996;7:382.

83. Collins M, Myers RM. Alterations in DNA helix stability due to base modifications can be evaluated using denaturating gradient gel electrophoresis. J Mol Biol 1987;198:737-44.

84. O'Donovan MC, Oefner PJ, Roberts SC, et al. Blind analysis of denaturing high-performance liquid chromatography as a tool for mutation detection. Genomics 1998;52:44-9.

85. Underhill PA, Jin L, Lin AA, et al. Detection of numerous Y chromosome biallelic polymorphisms by denaturing high-performance liquid chromatography. Genome Res 1997;7:996-1005.

86. Jones AC, Austin J, Hansen N, et al. Optimal temperature selection for mutation detection by denaturing HPLC and comparison to single-stranded conformation polymorphism and heteroduplex analysis. Clin Chem 1999;45:1133-40.

87. Schrijver I, Cherny SC, Zehnder JL. Testing for maternal cell contamination in prenatal samples: a comprehensive survey of current diagnostic practices in 35 molecular diagnostic laboratories. J Mol Diagn 2007;9:394-400.

88. Winsor EJ, Akoury H, Chitayat D, et al. The role of molecular microsatellite identity testing to detect sampling errors in prenatal diagnosis. Prenat Diagn 2010;30:74652 .
89. Stojilkovic-Mikic T, Mann K, Docherty Z, et al. Maternal cell contamination of prenatal samples assessed by QF-PCR genotyping. Prenat Diagn 2005;25:79-83.

90. Firth HV, Boyd PA, Chamberlain PF, et al. Analysis of limb reduction defects in babies exposed to chorionic villus sampling. Lancet 1994;343:1069-71.

91. Firth HV. Chorion villus sampling and limb deficiency - cause or coincidence? Prenat Diagn 1997;17:1313-30.

92. Tabor A, Philip J, Madsen M, et al. Randomised controlled trial of genetic amniocentesis in 4606 low-risk women. Lancet 1986;1:1287-93.

93. Sundberg K, Bang J, Smidt-Jensen S, et al. Randomised study of risk of fetal loss related to early amniocentesis versus chorionic villus sampling. Lancet 1997; 350:697-703.

94. Alfirevic Z. Early amniocentesis versus transabdominal chorion villus sampling for prenatal diagnosis. Cochrane Database Syst Rev 2000;(2):CD000077.

95. Boyd JD, Hamilton WJ. The human placenta. Cambridge, UK: Heffer; 1970.

96. Jauniaux E, Burton GJ, Moscoso GJ, et al. Development of the early human placenta: a morphometric study. Placenta 1991;12: 269-76.

97. Jurkovic D, Jauniaux E, Campbell S, et al. Coelocentesis: a new technique for early prenatal diagnosis. Lancet 1993;341:16234.

98. Findlay I, Atkinson G, Chambers M, et al. Rapid genetic diagnosis at 7-9 weeks gestation: diagnosis of sex, single gene defects and DNA fingerprint from coelomic samples. Hum Reprod 1996;11:2548-53.

99. Ross JA, Jurkovic D, Nicolaides K. Coelocentesis: a study of short-term safety. Prenat Diagn 1997;17:913-7.

100.Santolaya-Forgas J, Vengalil S, Kushwaha A, et al. Assessment of the risk of fetal loss after the coelocentesis procedure using a baboon model. Fetal Diagn Ther 1998;13: 257-60.

101.Jurkovic D, Jauniaux E, Campbell S, et al. Detection of sickle gene by coelocentesis in early pregnancy: a new approach to prenatal diagnosis of single gene disorders. Hum Reprod 1995;10:1287-9.

102.Jouannic JM, Tachdjian G, Costa JM, et al. Coelomic fluid analysis: the absolute necessity to prove its fetal origin. Reprod Biomed Online 2008;16:148-51.

103.Jouannic JM, Costa JM, Ernault P, et al. Very early prenatal diagnosis of genetic diseases based on coelomic fluid analysis: a feasibility study. Hum Reprod 2006; 21:2185-8.

104.Jauniaux E, Gulbis B. In vivo investigation of placental transfer early in human pregnancy. Eur J Obstet Gynecol Reprod Biol 2000;92:45-9.

105. Renda MC, Giambona A, Fecarotta E, et al. Embryo-fetal erythroid megaloblasts in the human coelomic cavity. J Cell Physiol 2010;225:385-9.

106. Rebello MT, Abas A, Nicolaides K, et al. Maternal contamination of amniotic fluid demonstrated by DNA analysis. Prenat Diagn 1994;14:109-12.

107.Cao A, Kan YW. The prevention of thalassemia. Cold Spring Harb Perspect Med 2012;3:a011775.

108.Phylipsen M, Yamsri S, Treffers EE, et al. Non-invasive prenatal diagnosis of $\beta$-thalassemia and sickle-cell disease using pyrophosphorolysis-activated polymerization and melting curve analysis. Prenat Diagn 2012;32:578-87.

109.Stembalska A, Slezak R, Pesz K, et al. Prenatal diagnosis - principles of diagnostic procedures and genetic counseling. Folia Histochem Cytobiol 2007;45:S11-6.

110.Koren A, Profeta L, Zalman L, et al. Prevention of $\beta$ Thalassemia in Northern Israel - a cost-benefit analysis. Mediterr J Hematol Infect Dis 2014;6:e2014012.

111.Giordano PC, Rachmilewitz E. The Price of Mercy: Comment to the Paper Entitled "Prevention of B Thalassemia In Northern Israel - A Cost-Benefit Analysis" by Koren et al. recently published in Mediterranean Journal of Hematology and Infectious Diseases. Mediterr J Hematol Infect Dis 2014;6:e2014022.

112.Al-Gazali L, Hamamy H, Al-Arrayad S. Genetic disease in the Arab world. BMJ 2006;333:831-4.

113.Tunçbilek E, Ozgüç M. Application of medical genetics in Turkey. Turk J Pediatr 2007;49:353-9. 